\title{
Diversity of organotrophic bacteria, activity of dehydrogenases and urease as well as seed germination and root growth Lepidium sativum, Sorghum saccharatum and Sinapis alba under the influence of polycyclic aromatic hydrocarbons
}

\author{
Aneta Lipińska $^{1}$. Jadwiga Wyszkowska ${ }^{1}$. Jan Kucharski ${ }^{1}$ \\ Received: 26 August 2014 / Accepted: 27 August 2015 /Published online: 5 September 2015 \\ (C) The Author(s) 2015. This article is published with open access at Springerlink.com
}

\begin{abstract}
Polycyclic aromatic hydrocarbons are organic compounds with highly toxic, carcinogenic, and mutagenic properties, which adversely affect the basic biological parameters of the soil, including the count of microorganisms, and the enzymatic activity. In addition to disturbances to the biological activity of the soil, PAHs may also exhibit toxic effects on plants. In view of the above, the study involved testing aimed at the determination of the effects of polycyclic aromatic hydrocarbons in a form of naphthalene, phenanthrene, anthracene and pyrene on the count, colony development (CD) index, ecophysiological (EP) diversity index of organotrophic bacteria, and the activity of soil dehydrogenases and soil urease. Moreover, an attempt was made to determine the soil's resistance based on the activity of the above-listed enzymes, and the effect of polycyclic aromatic hydrocarbons on seed germination and root growth was assessed by Lepidium sativum, Sorghum saccharatum, and Sinapis alba. In addition, the species of bacteria found in a soil subjected to strong pressure of polycyclic aromatic hydrocarbons were isolated. The experiment was performed in a laboratory on samples of loamy sand. Polycyclic aromatic hydrocarbons were introduced into the soil in an amount of 0,1000, 2000, and $4000 \mathrm{~m} \mathrm{~kg}^{-1}$ of soil dry matter. Germination and growth of cress (L. sativum), white mustard (S. alba), and sweet sorghum (S. saccharatum) were determined using Phytotoxkit tests. It was found that the tested PAHs increased the average colony counts of organotrophic soil bacteria; pyrene did so to
\end{abstract}

Responsible editor: Hailong Wang

Jadwiga Wyszkowska

jadwiga.wyszkowska@uwm.edu.pl

1 Department of Microbiology, University of Warmia and Mazury in Olsztyn, Plac Lodzki 3, 10-727 Olsztyn, Poland the greatest extent (2.2-fold relative to non-contaminated soil), phenanthrene to the smallest extent (1.4-fold relative to noncontaminated soil). None of the PAHs changed the value of the bacterial colony development (CD) index, while anthracene and pyrene increased the value of the eco-physiological (EP) diversity indicator. PAHs lowered the activity of the tested enzymes. The activity of dehydrogenases was dependent on a greater extent by the type of hydrocarbon $(54.56 \%)$ rather than by the dose $(10.64 \%)$, while for the activity of urease, it was the opposite. The greater extent was dependent on dose $(95.42 \%)$ rather than by type $(0.21 \%)$. Dehydrogenases are characterised by greater resistance to the action of PAHs than urease. Based on seed germination and root growth, it has shown that $S$. alba is best suited, being the most vulnerable plant, while $S$. saccharatum is the least suited. Subjecting a soil to strong pressure of PAHs leads to disturbances to the biological parameters of the soil, seed germination, and root growth L. sativum, S. saccharatum, and S. alba.

Keywords Polycyclic aromatic hydrocarbons · Colony development index $\cdot$ Ecophysiological diversity index $\cdot$ Soil resistance $\cdot$ Phytotoxkit test

\section{Introduction}

Environmental pollution with polycyclic aromatic hydrocarbons (PAHs) from oil spills, industrial processes, and atmospheric deposition poses a serious threat for water and land ecosystems (Driscoll et al. 2010; Maliszewska-Kordybach et al. 2013). Ecological functions, food safety, and human health are determined by the pool of PAHs released into the environment ( $\mathrm{Li}$ et al. 2013). Soil is a major reservoir for PAHs. Those toxic, carcinogenic, and lipophilic compounds (Amezcua-Allieri et al. 2012) bind to soil organic matter, 
which contributes to their persistence and stability in the soil environment (Wyszkowski and Ziółkowska 2013). PAHs significantly influence soil biological parameters (microbial counts and enzyme activity) that are the key determinants of soil quality. The results of various studies indicate that the stimulating or inhibitory effect of PAHs on microbial abundance and enzyme activity cannot be unequivocally established. Polycyclic aromatic hydrocarbons alter the microbiological and biochemical properties of soils (Wyszkowska and Kucharski 2000; Shen et al. 2005a, b). In addition, the action of PAHs is better represented by the soil enzymes, in particular dehydrogenases and urease, than the count of microorganisms (Wyszkowska et al. 2008; Lipińska et al. 2014a).

PAHs disrupt the biological activity of soil, and they can also exert toxic effects on plants, the basic source of raw materials for production. The inhibition of physiological processes in plants, which is manifested by chlorosis, yellowing, and reduced growth parameters, is one of the most characteristic symptoms of PAH contamination (Meudec et al. 2007). Therefore, our study tested the effects of naphthalene, phenanthrene, anthracene, and pyrene on seed germination and root growth Lepidium sativum, Sorghum saccharatum, and Sinapis alba.

Soil pollution with PAHs can be reversed through the application of remediation techniques that eliminate contaminating compounds and restore natural soil conditions. Soil remediation methods are expensive, which justify the continued search for cheaper and environmentally-friendly techniques. Bioremediation (Lin et al. 2010) is an effective method that relies on microorganisms capable of degrading PAHs. Microbial growth rates and, consequently, the rate and quality of biodegradation are determined by several factors, including temperature, soil moisture content, $\mathrm{pH}$, microbial diversity, and nutrient availability (Yessicaa et al. 2013). PAHs can be degraded by bacteria, fungi (Zafra et al. 2015), yeasts, and algae (Bundy et al. 2004), but bacteria play the key role in the process. Due to the natural potential of microorganisms that possess enzymatic capabilities, bioremediation is more effective when microbial consortia are used instead of individual isolates. Numerous bacterial genera (Pseudmonas, Bacillus, Micrococcus, Mycobacterium, Vibrio, Paenibacillus, Corynebacterium, Staphylococcus, and Aeromonas) have been identified and characterized based on their ability to degrade PAHs (Lin et al. 2010; Pedetta et al. 2013). The first stage in microbiological degradation of PAHs involves dioxygenase that inserts oxygen atoms between two carbon atoms in the benzene ring of a given PAH. The resulting cis-dihydrodiol is rearomatized by dehydrogenases to produce indirect dihydroxylyzed forms that cleave the ring and generate Krebs cycle products (Kanaly and Harayama 2000). Despite the wide availability of bacteria capable of metabolizing PAHs, new species are being discovered and subjected to genetic enhancement. For instance, the presence of the catA gene (catechol 1,2-dioxygenase gene) and the alkB gene (alkane 1-monooxygenase) indicates that selected species such as Gordonia spp. can be potentially used for bioremediation (Shen et al. 2009, 2010).

In view of the above, the study involved testing aimed at the determination of the effects of polycyclic aromatic hydrocarbons in a form of naphthalene, phenanthrene, anthracene, and pyrene on the count, colony development (CD) index, ecophysiological (EP) diversity index of organotrophic bacteria, and the activity of soil dehydrogenases and soil urease. Moreover, an attempt was made to determine the soil's resistance based on the activity of the above-listed enzymes, and the effect of polycyclic aromatic hydrocarbons on seed germination and root growth was assessed by L. sativum, S. saccharatum, and S. alba. In addition, the species of bacteria found in a soil subjected to strong pressure of polycyclic aromatic hydrocarbons were isolated.

\section{Materials and methods}

\section{Soil}

The experimental material comprised surface soil samples collected from the uppermost soil horizon $(0$ $20 \mathrm{~cm}$ ) at the Educational and Experimental Center in Tomaszkowo (NE Poland). The soils were classified as Eutric Cambisol on the World Reference Base of Soil Resources (2014). According to the graining classification of the United States Department of Agriculture, it was a soil with a granulometric composition of loamy sand (sand fraction-72.42\%, silt fraction-25.31\%, and colloidal clay fraction-2.27\%). The samples were dried and passed through a 2-mm mesh sieve. Grainsize composition of the soil was determined with laser method using a Mastersizer 2000. The $\mathrm{pH}$ of soil in $1 \mathrm{~mol} \mathrm{KCl} \mathrm{dm}{ }^{-3}$ was determined at 7.15 , hydrolytic acidity at $4.8 \mathrm{mmol}(+) \mathrm{kg}^{-1}$, total exchangeable base cations at $279 \mathrm{mmol}(+) \mathrm{kg}^{-1}$, organic carbon content at $13.1 \mathrm{~g} \mathrm{~kg}^{1}$, total nitrogen content at $1.1 \mathrm{~g} \mathrm{~kg}^{-1}$, available phosphorus content at $200 \mathrm{mg} \mathrm{kg}^{-1}$, potassium content at $147 \mathrm{mg} \mathrm{kg}^{-1}$, and magnesium content at $27 \mathrm{mg} \mathrm{kg}^{-1}$. Soil $\mathrm{pH}$ was determined by potentiometry in aqueous $\mathrm{KCl}$ solution of the concentration of $1 \mathrm{~mol}$

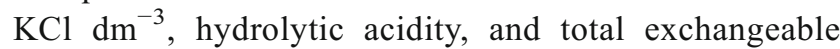
bases by the Kappen's method (Carter 1993), content of organic carbon-with Tiurin's method (Nelson and Sommers 1996), content of total nitrogen according to the method by Kjeldahl (ISO 11261. 1995), available phosphorus, potassium, and magnesium content by methods exactly described in the publication Kucharski and Wyszkowska (2000). The physicochemical properties of the soil were determined in three replications. 


\section{Polycyclic aromatic hydrocarbons}

Four organic compounds, naphthalene (B\&K Multi-branch Company), phenanthrene, anthracene, and pyrene (Acros Organics), were used as the model PAHs in the experiment. All of the tested compounds have been designated as priority pollutants by the US Environmental Protection Agency (US EPA). Soil samples were contaminated with powdered PAHs in the amount of $0,1000,2000$, and $4000 \mathrm{mg} \mathrm{kg}^{-1}$ dry matter of soil. The application of such high doses was justified by the amounts of PAHs that are released into the soil environment as a result of frequent and uncontrolled spills of petroleum derivatives (Park and Park 2011). Naphthalene, phenanthrene, anthracene, and pyrene are characterized by $\mathrm{n}$-octanol/water partition coefficients of 3.6, 4.46, 4.5, and 4.8, respectively; they are insoluble in water, but soluble in organic compounds.

\section{Experimental design}

One hundred fifty cubic centimeter glass beakers were filled with $100 \mathrm{~g}$ of soil. Ammonium nitrate $\left(\mathrm{NH}_{4} \mathrm{NO}_{3}\right)$ was added to each soil sample in the amount of $100 \mathrm{mg} \mathrm{kg}^{-1}$ dry matter of soil. The samples were contaminated with PAHs in the described doses. The samples were mixed, and demineralized water was added to $50 \%$ capillary water capacity. The samples were incubated for 32 weeks at room temperature without light access. Soil moisture was kept constant during incubation through the addition of demineralized water. The counts and structure of organotrophic bacteria and the activity of dehydrogenases and urease were determined after incubation. Microorganisms were isolated from soil samples and identified to the species level by BLIRT (BioLab Innovative Research Technologies) of Gdańsk.

\section{Determination of organotrophic bacteria counts}

Specimens of $10 \mathrm{~g}$ were collected from every soil sample and suspended in sterile saline solution to determine the population size of organotrophic bacteria. A series of dilutions were performed, and $1 \mathrm{~cm}^{3}$ of the selected suspension was plated in Bunt and Rovira medium (Bunt and Rovira 1955). The counts of organotrophic bacteria were determined in three replications. Organotrophic bacteria were counted daily for 10 days with the use of a colony counter, and microbial counts were determined based on the below formula:

$\mathrm{cfu}=\frac{\mathrm{a} \cdot \mathrm{n} \cdot 100}{\% \mathrm{DM}} \cdot 10^{3}$

where $\mathrm{a}$ is the number of colonies in a plate; $\mathrm{n}$ is the inverse of the dilution factor; $100 \%^{-1} \mathrm{DM}$ is the conversion factor to dry matter basis; $10^{3}$ is the conversion factor per $1 \mathrm{~kg}$ of soil.

\section{Determination of dehydrogenase and urease activity}

Dehydrogenase and urease activity was determined in three replications according to the methods proposed by Öhlinger (1996) and Alef and Nannipieri (1998). The substrate for dehydrogenase was $3 \%$ triphenyl-tetrazolium chloride (TTC) solution and for urease-urea. Soil samples were incubated for $24 \mathrm{~h}$ at $37^{\circ} \mathrm{C}$, and extinction was measured with the Aquarius CE7500 spectrophotometer (Cecil Instruments) at $485 \mathrm{~nm}$ for dehydrogenases and $410 \mathrm{~nm}$ for urease. The results were expressed in micromole TPF (triphenyl formazan) per kilogram soil DM per hour for dehydrogenases and in millimole $\mathrm{N}-\mathrm{NH}_{4}$ per kilogram soil DM per hour for urease.

\section{Determination of indicators of colony development, ecophysiological diversity, and soil resistance values}

Indicators of colony development (CD) and ecophysiological diversity (EP) were calculated to determine changes in microbial diversity of PAH-contaminated soil after 32 weeks of incubation. $\mathrm{CD}$ values were calculated based on the formula proposed by Saratchandra et al. (1997):

$\mathrm{CD}=\left(\mathrm{N}_{1} / 1+\mathrm{N}_{2} / 2+\mathrm{N}_{3} / 3+\ldots+\mathrm{N}_{10} / 10\right) \cdot 100$

where $\mathrm{CD}$ is the colony development index, $\mathrm{N}_{1}, \mathrm{~N}_{2}, \mathrm{~N}_{3}, \ldots$, $\mathrm{N}_{10}$ are the number of microbial colonies on day $1,2,3, \ldots$, 10 , expressed as a percentage of the total number of organotrophic bacteria counted daily for 10 days. The higher the value of $\mathrm{CD}$, the higher the rate of bacterial proliferation in the course of one or several days.

EP values were calculated using the formula proposed by DeLeij et al. (1994):

$\mathrm{EP}=-\sum\left(\mathrm{p}_{\mathrm{i}} \cdot \log 10 \mathrm{p}_{\mathrm{i}}\right)$

where EP is the ecophysiological diversity index, $\mathrm{p}_{\mathrm{i}}$ is the number of organotrophic bacterial colonies on a given day divided by the total number of microbial colonies. The higher the value of $\mathrm{ED}$, the more uniform the proliferation of microbial colonies in the analyzed period.

Soil resistance (RS) to contamination with PAHs was determined based on the formula proposed by Orwin and Wardle (2004):

$\operatorname{RS}\left(\mathrm{t}_{0}\right)=1-\frac{2\left|\mathrm{D}_{0}\right|}{\left(\mathrm{C}_{0}+\left|\mathrm{D}_{0}\right|\right)}$

where RS is the soil resistance index, $\mathrm{D}_{0}$ is the difference between control soil $\left(\mathrm{C}_{0}\right)$ and $\mathrm{PAH}-$ contaminated soil after 32 weeks of incubation $\left(t_{0}\right)$. The values of RS range from of -1 to 1 , where -1 and 0 imply that the pollutant has a very strong impact (200 and $100 \%$, respectively) on soil. The closer the RS values are to 1, the higher the soil's resistance 
to contamination, indicating that PAHs have a negligent effect or no effect on soil.

\section{Effect of PAHs on seed germination and root growth of Lepidium sativum, Sinapis alba, and Sorghum saccharatum}

Effect of PAHs on germination and growth of cress (L. sativum), white mustard (S. alba) and sweet sorghum (S. saccharatum) were determined using Phytotoxkit tests. After 32 weeks of incubation, $110 \mathrm{~g}$ samples of control soil and soil contaminated with a PAH dose of $4000 \mathrm{mg} \mathrm{kg}^{-1}$ dry matter of soil were placed on plastic plates. Ten seeds of each of the tested plants were placed on filter paper in three replications. The plates were incubated in vertical orientation at $25^{\circ} \mathrm{C}$ for 3 days. After incubation, percent inhibition of seed germination (SG) and percent inhibition of root growth (RI) were determined with the use of the below formula:

$\mathrm{SG}=(\mathrm{A}-\mathrm{B} / \mathrm{A}) \cdot 100, \mathrm{RI}=(\mathrm{A}-\mathrm{B} / \mathrm{A}) \cdot 100$

where A is the seed germination and root growth in control samples; B is the seed germination and root growth in experimental samples.

\section{Characterization of organotrophic bacteria}

Before culturing, $1 \mathrm{~g}$ specimens were collected from each soil sample (one control sample and four soil samples contaminated with naphthalene, phenanthrene, anthracene, and pyrene doses of $4000 \mathrm{mg} \mathrm{kg}^{-1}$ dry matter of soil and suspended in sterile saline solution at 1:10. After serial dilutions with saline solution, $1 \mathrm{~cm}^{3}$ of the resulting solution was placed on culture media in three replications.

In order to check the number of different groups of microorganisms, the following media were used for the isolation:

- PCA for determining total bacterial counts in food products, water, soil, and other substrates; cultures were prepared by the pour plate method, and the plates were incubated at $37^{\circ} \mathrm{C}$ for $96 \mathrm{~h}$;

- Baird-Parker selective agar for determining coagulasepositive staphylococci. The applied medium contains lithium chloride that inhibits the growth of associated microorganisms; cultures were prepared by the spread plate method, and the plates were incubated at $37^{\circ} \mathrm{C}$ for $48 \mathrm{~h}$;

- Sabouraud medium with chloramphenicol for determining molds, where the antibiotic inhibits the growth of nearly all associated microorganisms; cultures were prepared by the pour plate method, and the plates were incubated at $30{ }^{\circ} \mathrm{C}$ for $96 \mathrm{~h}$;

- VRBG selective agar for determining microorganisms of the family Enterobacteriaceae; due to the inclusion of the natural red indicator, bacteria that metabolize glucose into acids produce pink to red colonies that are often surrounded by a band of strontium yellow; cultures were prepared by the pour plate method, and the plates were incubated at $37^{\circ} \mathrm{C}$ for $48 \mathrm{~h}$.

After the determination of total microbial counts in PCA, the most characteristic and most rapidly proliferating colony was selected from each of the five Petri plates (one control sample and four experimental samples contaminated with PAHs). The selected colonies were labeled as $\mathrm{K}_{\mathrm{PCA}}, \mathrm{N}_{\mathrm{PCA}}$, $\mathrm{F}_{\mathrm{PCA}}, \mathrm{A}_{\mathrm{PCA}}$, and $\mathrm{P}_{\mathrm{PCA}}$. Every colony was transferred to an separate probe containing liquid PCA. The same procedure was applied to sample colonies from Baird-Parker agar, and the selected colonies were labeled as $\mathrm{K}_{\mathrm{BP}}, \mathrm{N}_{\mathrm{BP}}, \mathrm{F}_{\mathrm{BB}}, \mathrm{A}_{\mathrm{BP}}$, and $\mathrm{P}_{\mathrm{BP}}$. All cultures were incubated at $37^{\circ} \mathrm{C}$ for $24 \mathrm{~h}$.

Genomic DNA was extracted from strains with the use of the EXTRACTME DNA BACTERIA KIT (DNA Gdańsk). Products in the 16S-23S rDNA intergenic spacer region were amplified using PCR reagents supplied by DNA Gdańsk (Poland). Forward (AGA GTT TGA TCC TGG CTC AG) and reverse (GTG TGA CGG GCG GTG TGT AC) primers generating PCR products with the size of $1400 \mathrm{bp}$ were used in amplification. For the PCR reaction, a reaction mixture was used with the following composition: $2.5 \mathrm{~mm}^{3}$ of buffer, $5 \mathrm{~mm}^{3}$ of Q-solution, $1.6 \mathrm{~mm}^{3}$ of a solution of four deoxyribonucleoside triphosphates (dNTP), $1 \mathrm{~mm}^{3}$ of $\mathrm{MgCl}_{2}$ (magnesium ions are cofactors of Taq polymerase), a couple of starters (reverse and forward), $7.65 \mathrm{~mm}^{3}$ of water free of RNases, and $0.25 \mathrm{~mm}^{3}$ of Taq polymerase. The conditions of the PCR reaction were the following: initial denaturation temperature $-95^{\circ} \mathrm{C}$, time $-3 \mathrm{~min}$; denaturation temperature$95^{\circ} \mathrm{C}$, time $-0.5 \mathrm{~min}$; heating temperature $-57^{\circ} \mathrm{C}$, time$1 \mathrm{~min}$; elongation temperature $-72^{\circ} \mathrm{C}$, time $-1 \mathrm{~min}$; final elongation temperature $-72{ }^{\circ} \mathrm{C}$, time $-7 \mathrm{~min}$; cooling temperature $-4{ }^{\circ} \mathrm{C}$; number of cycles- 35 .

After the PCR reaction, reaction mixtures were separated in $1.5 \%$ agarose gel to inspect the quality of amplified products. PCR products were extracted from gel and purified with the use of the EXTRACTME DNA GEL-OUT KIT. PCR products were sequenced in both directions in the 3730 XL DNA Analyzer (Life Technologies). The results were analyzed with the use of the NCBI database and BLAST software.

In the group of the examined bacterial strains, nucleotide sequences with the length of $1400 \mathrm{bp}$ were selected based on their percentage share in the identified species. All sequences were aligned in Clustal W (MEGA 6.0 tool). The phylogenetic tree was developed by the neighbor-joining method.

\section{Statistical analysis}

The results of laboratory tests performed in three replications were processed by ANOVA in the Statistica 9.1 application 
(StatSoft 2010). The homogeneity of variance was analyzed by Tukey's test at a significance level of $p=0.01$. Dehydrogenase and urease activity and the counts of organotrophic bacteria were visualized by PCA. The proportion of variation attributed to dehydrogenase and urease activity and the counts of organotrophic bacteria was determined by eta-squared calculations. The coefficients of correlation between the degree of soil contamination with PAHs and the abundance of organotrophic bacteria, dehydrogenase and urease activity, and soil resistance were determined in Excel.

\section{Results and discussion}

\section{Abundance and structure of organotrophic bacteria in PAH-contaminated soil}

High doses of PAHs initially inhibit microbial growth when soil-dwelling microorganisms come into contact with new environmental stressors. After a period of stagnation in soils contaminated with PAHs, new populations of bacteria, Actinobacteria and fungi emerge, and microbial metabolism lead to the degradation of PAHs (Baran et al. 2004; Shen et al. 2005a). The counts of organotrophic bacteria varied under the influence of PAHs and were significantly correlated with the dose and type of the applied PAHs, which explained variation in 63.59 and $17.35 \%$, respectively (Table 1). The abundance of the analyzed bacteria increased with a rise in contamination levels, and the highest average colony counts were noted in soil samples treated with pyrene (Table 2). The pyrene dose of $4000 \mathrm{mg} \mathrm{kg}^{-1}$ dry matter of soil increased the abundance of organotrophic bacteria 2.9-fold relative to control. Pyrene, as the first of the PAHs, is included in the group of hydrocarbons of high molecular weight, which in turn leads to its increased stability in the soil, and translates into a stronger effect towards microorganisms. Even after a period of 32 weeks, microorganisms were able to use this hydrocarbon as a carbon donor. The variable representing organotrophic bacterial counts in the PCA diagram (Fig. 1) lies closer to the horizontal axis and explains $62.32 \%$ of the variation. The lowest average microbial abundance was observed in soil samples contaminated with

Table 1 Percentage of independent variables factors (type of PAHs and dose of PAHs) $\eta^{2}$ in the formation number of organotrophic bacteria and soil dehydrogenases and urease activity

\begin{tabular}{lccr}
\hline Variables & Organotrophic bacteria & Dehydrogenases & Urease \\
\hline Type of PAHs & 17.35 & 54.56 & 0.21 \\
Dose of PAHs & 63.59 & 10.64 & 95.42 \\
Type dose of PAHs & 13.86 & 33.66 & 3.40 \\
Error & 5.20 & 1.14 & 0.96 \\
\hline
\end{tabular}

$\eta^{2}$ processed by ANOVA in the Statistica 9.1. phenanthrene, which is illustrated by the greatest distance between points 6,10 , and 14 and the vector representing organotrophic bacteria. In initial stages, PAHs constitute a robust source of energy and carbon for microorganisms whose energy demand increases under exposure to new environmental stressors (Margesin et al. 2000). Wyszkowska and Kucharski (2005) reported on Diesel oil's stimulating effect on the counts of bacteria, Actinobacteria, copiotrophic bacteria, sporeforming copiotrophic bacteria, and oligotrophic bacteria. The development of organotrophic bacteria could be determined by the introduction of high doses of PAHs to the soil, but having considered the decreasing activity of dehydrogenases, a different reason for the increasing count of microorganisms may be assumed. Following the application of naphthalene, phenanthrene, anthracene, and pyrene to the soil, some microorganisms could probably have died in the soil. This is why a lowered activity of dehydrogenases was recorded in the study. The cells of microorganisms which were lysed provided a substrate to other microorganisms occurring in the soil. Hence, the increased count of bacteria was found (Hicks et al. 1990).

According to the $\mathrm{r} / \mathrm{K}$ selection theory, genetic differences between microorganisms enable microbes to survive in diverse environments (De Leij et al. 1994). The development of bacterial colonies on each day of the analyzed period can be monitored with the use of $C D$ index values in the range of 0 to 100. CD values are higher when microbial populations proliferate within a short period of time relative to the entire experimental period. In this study, CD values remained fairly stable regardless of the dose and type of PAHs (Fig. 2). The highest average value of $\mathrm{CD}$ was noted in samples treated with anthracene (27.27) and the lowest in samples contaminated with phenanthrene (26.38). Our findings could indicate that microorganisms had successfully adapted to an environment contaminated with PAHs. After 32 weeks of incubation, there was a high probability of development towards K-strategists and slow-growing microorganisms that easily adapt to changing environmental conditions (DeLeij et al. 1994; Saratchandra et al. 1997), even after a period of significant contamination with PAHs. The above assumption is validated by the identification of bacterial species, most of which were autochthonous microbes (K-strategists) with possible genetic changes that contribute to survival in unsupportive environments.

The CD index is related to the EP index whose values ranged from 0.68 to 0.91 , subject to the applied dose and type of PAHs. The highest average EP values were reported in soil treated with pyrene (Fig. 3) (0.86), and the lowest EP values were reported in samples contaminated with phenanthrene (0.74). Bacterial proliferation could be conditioned by the bioavailability of PAHs resulting from the structure of those organic compounds. EP values reflect the uniformity of growth of orghanotrophic bacteria over a given period of time. EP values range from 0 to 1 , and the higher the value of the indicator, the more uniform the growth of the examined microorganisms. 
Table 2 The number of organotrophic bacteria in soil contaminated with PAHs

\begin{tabular}{lllll}
\hline Dose of PAHs (mg kg ${ }^{-1}$ DM soil) & \multicolumn{2}{l}{ Type of PAHs } & & \\
\cline { 2 - 5 } & $\begin{array}{l}\text { Naphthalene } \\
10^{9} \mathrm{cfu} \mathrm{kg}^{-1} \text { DM soil }\end{array}$ & $\begin{array}{l}\text { Phenanthrene } \\
\text { Anthracene }\end{array}$ & Pyrene \\
\hline 0 & $18.25 \mathrm{a}^{\mathrm{a}}$ & $18.25 \mathrm{a}$ & $18.25 \mathrm{a}$ & $18.25 \mathrm{a}$ \\
1000 & $23.25 \mathrm{~b}$ & $22.47 \mathrm{~b}$ & $32.25 \mathrm{~b}$ & $35.72 \mathrm{~b}$ \\
2000 & $34.22 \mathrm{c}$ & $27.67 \mathrm{bc}$ & $39.48 \mathrm{c}$ & $50.68 \mathrm{c}$ \\
4000 & $44.36 \mathrm{~d}$ & $31.12 \mathrm{c}$ & $63.70 \mathrm{~d}$ & $52.79 \mathrm{c}$ \\
average & 30.02 & 24.87 & 38.42 & 39.36 \\
$r$ & 0.98 & 0.96 & 0.99 & 0.88 \\
\hline
\end{tabular}

${ }^{\mathrm{a}}$ In columns homogenous groups are followed by the same letter

$r$ correlation coefficient

\section{Dehydrogenase and urease activity in PAH-contaminated soil}

The quantity and quality of pollutants introduced to the soil environment significantly affect enzymatic activity, which is one of the key biological indicators of soil quality. Dehydrogenases and urease are enzymes that are most sensitive to external stressors, and in contaminated substrates, their activity is stimulated or inhibited relative to control. In this study, the PAH dose significantly influenced dehydrogenase and urease activity. The PCA diagram (Fig. 1) presents the activity levels of dehydrogenases and urease and points representing different doses of PAHs. The urease activity vector lies closer to the horizontal axis, and it explains $62.32 \%$ of the variation (Fig. 1). Urease activity was highly significantly correlated with the PAH dose, and it explained $95.42 \%$ of the variation (Table 1 ). Urease activity decreased with an increase in the PAH dose (Table 4), and the observed changes were significant already at the dose of $1000 \mathrm{mg} \mathrm{kg}^{-1}$ dry matter of soil, which is reflected by the proximity of points 5-8 representing the above dose in the PCA chart. Variations in dehydrogenase activity were explained by the PAH dose in $10.64 \%$ (Table 1) and by the type of the applied PAH in $54.56 \%$. Dehydrogenase was most strongly inhibited by phenanthrene, which is demonstrated by the greatest distance between points 6,10 , and 14

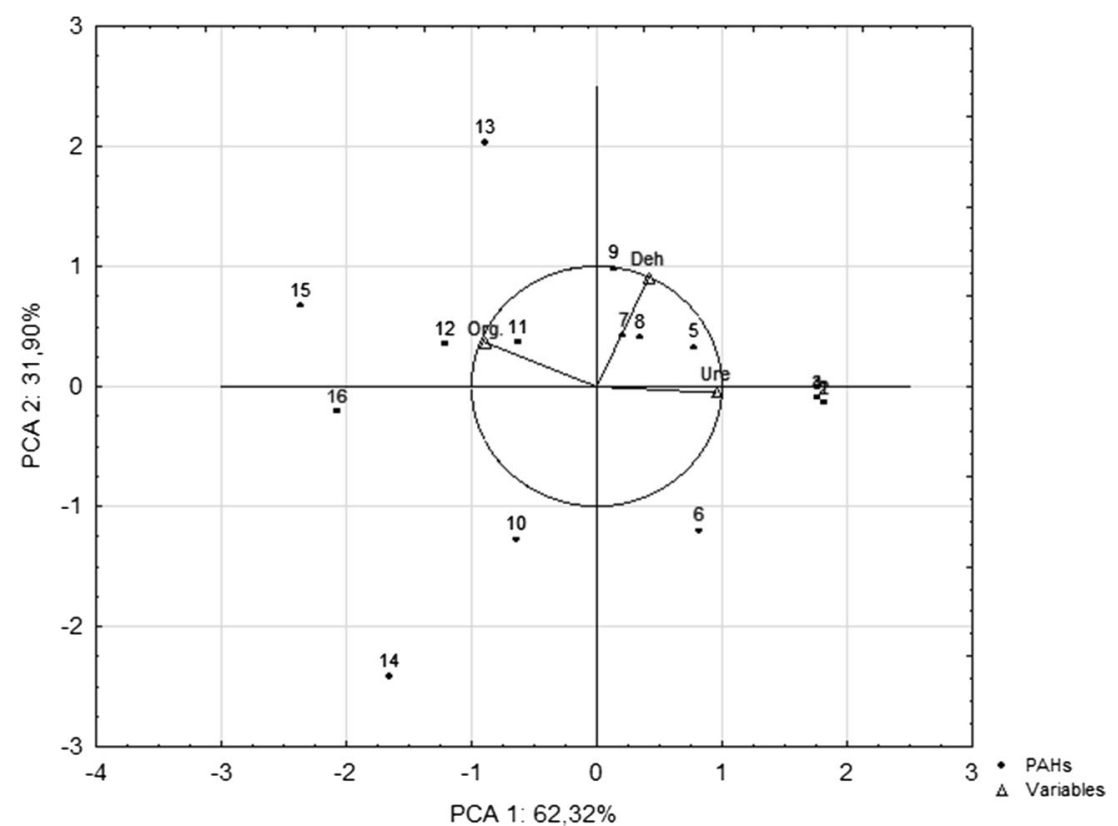

Fig. 1 The number of organotrophic bacteria, dehydrogenase, and urease activity in loamy sand contaminated with PAHs determined by the PCA method. Explanations: Org.--organotrophic bacteria, Dehdehydrogenases; Ure - urease; 1-4 control samples without PAHs, 58 - samples contaminated with naphthalene, phenanthrene, anthracene, and pyrene doses of $1000 \mathrm{mg} \mathrm{kg}^{-1}$ soil DM, respectively; 9-12samples contaminated with naphthalene, phenanthrene, anthracene, and pyrene doses of $2000 \mathrm{mg} \mathrm{kg}^{-1}$ soil DM, respectively; 13-16 - samples contaminated with naphthalene, phenanthrene, anthracene, and pyrene doses of $4000 \mathrm{mg} \mathrm{kg}^{-1}$ soil DM, respectively 
Fig. 2 Indices of colony development (CD) of organotrophic bacteria in soil contaminated with PAHs. Error bars represent standard deviation $(n=9)$

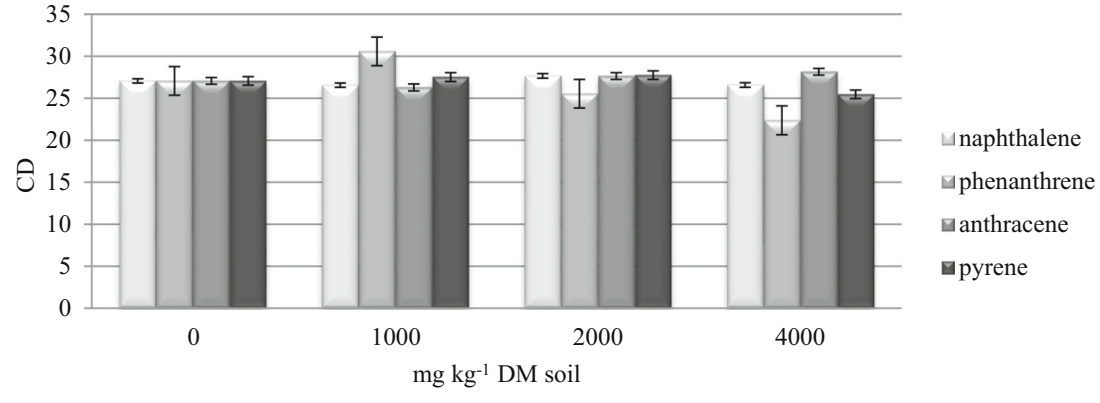

(Fig. 1) and the vectors of variables. Anthracene had the least inhibitory effect on dehydrogenase activity (Table 3), whereas urease activity was least suppressed by pyrene (Table 4$)$. Shen et al. (2005a, b) demonstrated that phenanthrene, fluoranthene, and benzo(a)pyrene had a negative effect on the activity of the discussed enzymes. PAHs are highly toxic, and they inhibit most soil enzymes (Wyszkowska and Kucharski 2000; Lipińska et al. 2013). In some reports, however, PAHs had a stimulating effect on the biochemical activity of soil. Klimkowicz-Pawlas and Maliszewska-Kordybach (2003) evaluated the impact of anthracene and pyrene on dehydrogenase activity and reported an increase in enzymatic activity in samples freshly contaminated with PAHs. In a study of soil contaminated with diesel oil doses of $3,6,9,12,24$, and $10 \mathrm{~cm}^{3} \mathrm{~kg}^{-1}$ dry matter of soil, the activity of dehydrogenases, urease, and alkaline phosphatase increased relative to control (Wyszkowska et al. 2006; Wyszkowska et al. 2008). The number of benzene rings determines a PAH's ability to stimulate enzymatic activity. Organic compounds containing three or four rings constitute a rich source of energy and carbon for microorganisms, whereas compounds containing a higher number of rings are toxic, mutagenic, and carcinogenic (Baran et al. 2004; Shen et al. 2005b). Regardless of the applied PAH dose, the lowest average level of dehydrogenase activity was noted in soil treated with phenanthrene. The above results could be linked to the counts of organotrophic bacteria, which were also lowest in soil contaminated with phenanthrene. Even high doses of the analyzed pollutant could have been utilized in early stages of the experiment.

\section{Soil resistance (RS) to contamination with PAHs}

There is a general scarcity of studies investigating soil resistance based on the activity of soil enzymes (Wyszkowska et al. 2013; Lipińska et al. 2014a, b). Soil resistance is generally defined as the stability of the soil ecosystem after exposure to external factors, mostly anthropogenic stressors. Other factors include soil type, type of land use, and climate (Orwin and Wardle 2004). Orwin and Wardle (2004) proposed a method for calculating RS values in the range of -1 to 1 . RS of 1 implies $100 \%$ soil resistance and an absence of environmental stressors. The closer the RS values are to -1 , the greater the influence of external factors, and RS of -1 points to $200 \%$ influence of the stressor. The resistance of loamy sand, calculated based on dehydrogenase and urease activity, varied subject to the dose and type of PAHs. RS values decreased with an increase in soil contamination with naphthalene, phenanthrene, anthracene, and pyrene (Table 5). The lowest average RS values were noted in soil treated with phenanthrene. The highest average RS values were observed in soil contaminated with anthracene, which was characterized by the smallest drop in dehydrogenase activity and in soil treated with pyrene, which was characterized by the lowest decrease in urease activity.

\section{Bacteria occurring in a soil contaminated with PAHs}

Anthracene and pyrene had the most stimulating influence on the abundance of organotrophic bacteria and soil-dwelling microorganisms. The highest total counts of bacteria and molds were determined in soil samples treated with anthracene, where microbial abundance was 1.34 -fold and 4-fold
Fig. 3 Ecophysiological diversity index (EP) of organotrophic bacteria in soil contaminated with PAHs. Error bars represent standard deviation $(n=9)$

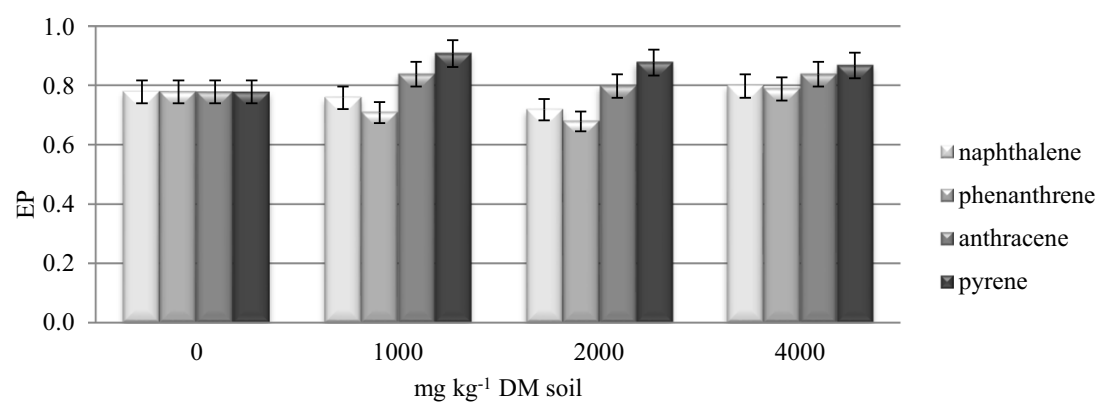


Table 3 Activity of dehydrogenases in soil contaminated with PAHs

\begin{tabular}{|c|c|c|c|c|}
\hline \multirow[t]{2}{*}{ Dose of PAHs (mg kg ${ }^{-1} \mathrm{DM}$ soil) } & \multicolumn{4}{|l|}{ Type of PAHs } \\
\hline & $\begin{array}{l}\text { Naphthalene } \\
\mu \text { mol TFF } \mathrm{kg}^{-1} \mathrm{D}\end{array}$ & $\begin{array}{l}\text { Phenanthrene } \\
M \text { soil h}^{-1}\end{array}$ & Anthracene & Pyrene \\
\hline 0 & $8.62 \mathrm{c}^{\mathrm{a}}$ & $8.62 \mathrm{c}$ & $8.63 \mathrm{~b}$ & $8.63 \mathrm{c}$ \\
\hline 1000 & $8.93 \mathrm{c}$ & $7.10 \mathrm{~b}$ & $8.73 \mathrm{~b}$ & $8.62 \mathrm{c}$ \\
\hline 2000 & $7.25 \mathrm{~b}$ & $6.73 \mathrm{~b}$ & $8.37 \mathrm{ab}$ & $7.98 \mathrm{~b}$ \\
\hline 4000 & $6.21 \mathrm{a}$ & $5.15 \mathrm{a}$ & $7.87 \mathrm{a}$ & $7.16 \mathrm{a}$ \\
\hline average & 7.75 & 6.90 & 8.40 & 8.10 \\
\hline$r$ & -0.93 & -0.98 & -0.94 & -0.97 \\
\hline
\end{tabular}

${ }^{\mathrm{a}}$ In columns homogenous groups are followed by the same letter

$r$ correlation coefficient

higher than in control, respectively, (Table 7). Staphylococci proliferated most rapidly in soil contaminated with pyrene where microbial counts increased 2.16-fold in comparison with control. The highest growth rate of Enterobacteriaceae on VRBG agar was reported in samples treated with naphthalene (355.5-fold higher in comparison with control) (Table 6). Anthracene, a three-ring PAH, is often used in studies of PAH biodegradation. During 32 weeks of incubation, microorganisms exposed to high doses of anthracene gradually decomposed and utilized hydrocarbons as a source of carbon in the process of adapting to new environmental conditions. The second most influential PAH was pyrene, a model compound in studies investigating the biodegradation of highmolecular-weight hydrocarbons. High pyrene doses probably contributed to the gradual release of carbon, which increased staphylococci counts.

Bacterial isolates were identified to the species level by 16SrDNA sequence analysis because every taxon has one or more unique 16S-rDNA nucleotide sequences. Nucleotide sequences of every tested isolate with the length of $1400 \mathrm{bp}$ were amplified and sequenced, and PCR efficiency was validated by electrophoresis. The majority of bacteria cultured on PCA belonged to the genus Bacillus (Table 7), which is widely used in PAH degradation. Based on an analysis of the NCBI database, the greatest sequence similarity of bacteria cultured on PCA in the control sample was noted for Bacillus frigoritolerans, Bacillus simplex, and unclassified strains of the genus Bacillus with $99 \%$ sequence similarity. The species identified in soil samples containing naphthalene were $B$. frigoritolerans, Bacillus thuringiensis, Bacillus muralis, B. simplex, and unclassified strains of the genus Bacillus. The strains isolated from phenanthrene-contaminated soil were identified as B. frigoritolerans, B. muralis, B. simplex, and unclassified strains of the genus Bacillus. The following taxa were identified in soil contaminated with anthracene: Bacillus pumilus, Bacillus safensis, and unclassified strains of the genus Bacillus. The soil sample treated with pyrene was colonized by bacterial species of $B$. frigoritolerans, $B$. thuringiensis, $B$. simplex, and unclassified strains of the genus Bacillus.

The following Staphylococcus species were identified on Baird-Parker agar in the control sample: Bacillus psychrodurans and unclassified strains of the genus Bacillus. Based on an analysis of the NCBI database, the greatest sequence similarity was noted for Paenibacillus alvei, Paenibacillus apiarius, Paenibacillus taiwanensis, and unclassified strains of the genus Paenibacillus. Soil contaminated with phenanthrene was colonized by B. pumilus, B. safensis, Bacillus aerophilus, Bacillus altitudinis, and unclassified strains of the
Table 4 Activity of urease in soil contaminated with PAHs

\begin{tabular}{|c|c|c|c|c|}
\hline \multirow[t]{2}{*}{ Dose of PAHs (mg kg ${ }^{-1} \mathrm{DM}$ soil) } & \multicolumn{4}{|l|}{ Type of PAHs } \\
\hline & $\begin{array}{l}\text { Naphthalene } \\
\text { mmol N-NH} \mathrm{kg}^{-1} \mathrm{I}\end{array}$ & $\begin{array}{l}\text { Phenanthrene } \\
\text { DM soil } h^{-1}\end{array}$ & Anthracene & Pyrene \\
\hline 0 & $2.76 \mathrm{c}^{\mathrm{a}}$ & $2.76 \mathrm{~d}$ & $2.76 \mathrm{~d}$ & $2.76 \mathrm{c}$ \\
\hline 1000 & $2.00 \mathrm{~b}$ & $2.43 \mathrm{c}$ & $1.93 \mathrm{c}$ & $2.22 \mathrm{c}$ \\
\hline 2000 & $1.80 \mathrm{~b}$ & $1.44 \mathrm{~b}$ & $1.57 \mathrm{~b}$ & $1.63 \mathrm{~b}$ \\
\hline 4000 & $1.11 \mathrm{a}$ & $1.06 \mathrm{a}$ & $1.18 \mathrm{a}$ & $1.14 \mathrm{a}$ \\
\hline average & 1.91 & 1.92 & 1.86 & 1.93 \\
\hline$r$ & -0.97 & -0.95 & -0.93 & -0.98 \\
\hline
\end{tabular}

${ }^{\mathrm{a}}$ In columns homogenous groups are followed by the same letter

$r$ correlation coefficient 
Table 5 Soil resistance (RS) to contamination with PAHs

\begin{tabular}{lllll}
\hline Dose of PAHs (mg kg ${ }^{-1} \mathrm{DM}$ soil) & \multicolumn{2}{l}{ Type of PAHs } & & \\
\cline { 2 - 4 } & naphthalene & phenanthrene & anthracene & pyrene \\
\hline Dehydrogenases & & & & \\
1000 & $0.929 \mathrm{c}^{\mathrm{a}}$ & $0.700 \mathrm{c}$ & $0.956 \mathrm{~b}$ & $0.981 \mathrm{c}$ \\
2000 & $0.847 \mathrm{~b}$ & $0.641 \mathrm{~b}$ & $0.942 \mathrm{~b}$ & $0.859 \mathrm{~b}$ \\
4000 & $0.687 \mathrm{a}$ & $0.427 \mathrm{a}$ & $0.839 \mathrm{a}$ & $0.709 \mathrm{a}$ \\
average & 0.821 & 0.589 & 0.912 & 0.849 \\
$\mathrm{r}$ & -0.99 & -0.99 & -0.97 & -0.99 \\
Urease & & & & \\
1000 & $0.571 \mathrm{c}$ & $0.164 \mathrm{~b}$ & $0.539 \mathrm{c}$ & $0.672 \mathrm{c}$ \\
2000 & $0.483 \mathrm{~b}$ & $0.091 \mathrm{a}$ & $0.399 \mathrm{~b}$ & $0.419 \mathrm{~b}$ \\
4000 & $0.254 \mathrm{a}$ & $0.065 \mathrm{a}$ & $0.274 \mathrm{a}$ & $0.260 \mathrm{a}$ \\
average & 0.436 & 0.106 & 0.404 & 0.450 \\
$\mathrm{r}$ & -0.99 & -0.89 & -0.97 & -0.94 \\
\hline
\end{tabular}

${ }^{\mathrm{a}}$ In columns for individual enzymes homogenous groups are followed by the same letter $r$ correlation coefficient genus Bacillus. The bacterial species identified in samples treated with anthracene were Corynebacterium amycolatum and unclassified strains of the genus Corynebacterium, and in samples contaminated with pyrene-B. pumilus, B. safensis, B. aerophilus, and unclassified strains of the genus Bacillus. The phylogenetic tree was developed to illustrate evolutionary correlations between the most characteristic strains isolated from PAH-contaminated soil (Fig. 4).

The majority of bacteria identified in this study belonged to the genus Bacillus sp., and their significance had been described in earlier research. The potential role of Bacillus sp. species in degrading PAHs was explored in numerous reports (Toledo et al. 2006; Seo et al. 2009). Pelaez et al. (2013) observed a reduction in PAH contamination levels after the application of autochthonous bacteria of the genera Bacillus and Pseudomonas. Moscoso et al. (2012) examined the biodegradation of three PAHs: phenanthrene, pyrene, and benzo(a)anthracene. A consortium of Staphylococcus warneri and B. pumilus effectively reduced $85 \%$ of each of the tested hydrocarbons in a laboratory and degraded more than $90 \%$ of the analyzed PAHs in a bioreactor over a period of three days. Bacillus fusiformis isolated from wastewater sludge contaminated with petroleum can be used to degrade naphthalene. Under optimal conditions, i.e., at a temperature of $30{ }^{\circ} \mathrm{C}$ and $\mathrm{pH}$ of 7 , naphthalene was removed by the analyzed strain in $99.1 \%$ in four days (Lin et al. 2010). Das and Mukherjee (2007) studied the effectiveness of the Bacillus subtilis DM04 strain and reported a significant reduction in the levels of petroleum- and oil-derived PAHs. In the work of Xiao et al. (2012), a biosurfactant produced by B. subtilis stimulated mycelial growth under exposure to PAHs. Inoculation with the biosurfactant produced by B. subtilis and Glomus etunicatum fungi significantly reduced phenanthrene concentrations in soil and increased the activity of catalase and polyphenol oxidase.

\section{Effect of PAHs on seed germination and root growth of: Lepidium sativum, Sorghum saccharatum, and Sinapis alba}

The effects of PAHs were determined based on analysis of seed germination and root growth in cress, sweet sorghum, and white mustard. Regardless of the applied PAH dose, seed germination was most inhibited in L. sativum (11.6\%), followed by S. alba $(6.6 \%)$ and S. saccharatum $(1.6 \%)$. A decrease in root length

Table 6 The number of bacteria, staphylococci, molds, Enterobacteriaceae in soil contaminated with PAHs

\begin{tabular}{|c|c|c|c|c|c|}
\hline Microorganisms & Control & Naphthalene & Phenanthrene & Anthracene & Pyrene \\
\hline \multicolumn{6}{|c|}{ Number of microorganisms $\left(10^{7} \mathrm{cfu} \mathrm{kg}{ }^{-1} \mathrm{DM}\right.$ soil $)$} \\
\hline Number of bacteria & $115 \pm 18$ & $38 \pm 4$ & $90 \pm 9$ & $154 \pm 14$ & $43 \pm 7$ \\
\hline \multicolumn{6}{|c|}{ Number of microorganisms $\left(10^{3} \mathrm{cfu} \mathrm{kg}^{-1} \mathrm{DM}\right.$ soil $)$} \\
\hline Staphylococci & $240 \pm 22$ & $430 \pm 25$ & $250 \pm 15$ & $450 \pm 21$ & $520 \pm 32$ \\
\hline Molds & $9 \pm 2$ & $9 \pm 1$ & $8 \pm 2$ & $36 \pm 7$ & $25 \pm 4$ \\
\hline Enterobacteriaceae & $9 \pm 3$ & $3200 \pm 103$ & $300 \pm 21$ & $1600 \pm 86$ & $200 \pm 20$ \\
\hline
\end{tabular}


Table 7 Microbial strains identified in soil samples contaminated with PAHs

\begin{tabular}{|c|c|c|c|c|c|}
\hline \multirow[t]{2}{*}{ Type/species } & \multicolumn{5}{|c|}{ Type of PAHs } \\
\hline & Control & Naphthalene & Phenanthrene & Anthracene & Pyrene \\
\hline \multicolumn{6}{|l|}{ Strains from PCA medium } \\
\hline Bacillus frigoritolerans & + & + & + & - & + \\
\hline Bacillus simplex & + & + & + & - & + \\
\hline Bacillus thuringiensis & - & + & - & - & + \\
\hline Bacillus muralis & - & + & + & - & - \\
\hline Bacillus pumilus & - & - & - & + & - \\
\hline Bacillus safensis & - & - & - & + & - \\
\hline Unclassified strains of Bacillus & + & + & + & + & + \\
\hline \multicolumn{6}{|l|}{ Strains from Baird-Parker agar } \\
\hline Bacillus psychrodurans & + & - & - & - & - \\
\hline Bacillus pumilus & - & - & + & - & + \\
\hline Bacillus safensis & - & - & + & - & + \\
\hline Bacillus aerophilus & - & - & + & - & + \\
\hline Bacillus altitudinis & - & - & + & - & - \\
\hline Corynebacterium amycolatum & - & - & - & + & - \\
\hline Paenibacillus alvei & - & + & - & - & - \\
\hline Paenibacillus apiarius & - & + & - & - & - \\
\hline Paenibacillus taiwanensis & - & + & - & - & - \\
\hline Unclassified strains of Bacillus & + & - & + & - & + \\
\hline Unclassified strains of Paenibacillus & - & + & - & - & - \\
\hline Unclassified strains of Corynebacterium & - & - & - & + & - \\
\hline
\end{tabular}

"+” presence of the strain in soil sample; “-” absent in soil sample relative to control was observed in L. sativum and S. alba where root growth was inhibited by 17.7 and $28.0 \%$ on average, respectively, (Table 8). The most PAH-resistant plant was sweet sorghum whose roots increased in length under exposure to PAHs in comparison with control. Irrespective of the plant species, seed germination was most inhibited by pyrene (11.1\%), whereas phenanthrene had the most inhibitory effect on root growth $(20.6 \%)$ in the analyzed plants.
Root growth was inhibited or stimulated subject to plant species and the applied PAHs. The greatest root elongation was reported in $S$. saccharatum, which was most resistant to PAH contamination. A stimulating influence of PAHs on plant growth was also reported by other authors (Smreczak and Maliszewska-Kordybach 2003). When applied at the dose of $4000 \mathrm{mg} \mathrm{kg}^{-1}$ soil DM, each of the analyzed PAHs were toxic for L. sativum and S. alba. Smreczak and MaliszewskaKordybach (2003) demonstrated that a mixture of PAHs

Fig. 4 Phylogenetic tree of genetic similarity between selected bacterial strains isolated from PAH-contaminated soil

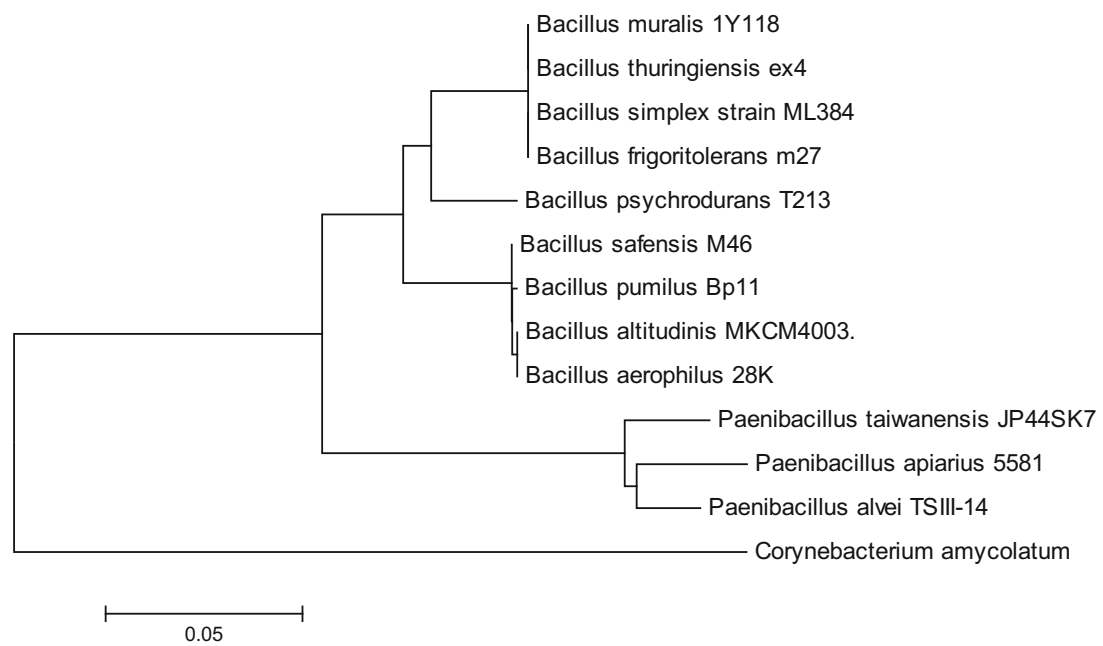


Table 8 Effects of PAHs on seed germination and root growth of Lepidium sativum, Sorghum saccharatum, and Sinapis alba

\begin{tabular}{|c|c|c|c|c|}
\hline \multirow[t]{2}{*}{ Plant } & \multicolumn{4}{|l|}{ Type of PAHs } \\
\hline & Naphthalene & Phenanthrene & Anthracene & Pyrene \\
\hline \multicolumn{5}{|c|}{ Inhibition of seed germination (\%) } \\
\hline L. sativum & $20.0 \mathrm{a}^{\mathrm{a}}$ & $10.0 \mathrm{abc}$ & $0.0 \mathrm{c}$ & $16.6 \mathrm{ab}$ \\
\hline S.saccharatum & $0.0 \mathrm{c}$ & $0.0 \mathrm{c}$ & $6.6 \mathrm{abc}$ & $0.0 \mathrm{c}$ \\
\hline S. alba & $6.6 \mathrm{abc}$ & $0.0 \mathrm{c}$ & $3.3 \mathrm{bc}$ & $16.6 \mathrm{ab}$ \\
\hline \multicolumn{5}{|c|}{ Inhibition of root growth (\%) } \\
\hline L. sativum & $16.2 \mathrm{~cd}$ & $22.5 \mathrm{abc}$ & $16.4 \mathrm{~cd}$ & $15.9 \mathrm{~cd}$ \\
\hline S.saccharatum & $9.3 \mathrm{~cd}$ & $-1.25 \mathrm{~d}$ & $-22.7 \mathrm{e}$ & $-23.2 \mathrm{e}$ \\
\hline S. alba & $21.8 \mathrm{bc}$ & $40.4 \mathrm{a}$ & $37.9 \mathrm{ab}$ & $11.9 \mathrm{~cd}$ \\
\hline
\end{tabular}

Negative values indicate PAHs' stimulating effect on root growth in the examined plant species

${ }^{a}$ Homogenous groups for inhibition of seed germination and root growth are followed by the same letter

inhibited plant growth already at the dose of $100 \mathrm{mg} \mathrm{kg}^{-1}$ soil DM. In our studies, phenanthrene had the most inhibitory effect on the growth of all evaluated plants. Phenanthrene was the hydrocarbon which also inhibited the development of organotrophic bacteria and the activity of dehydrogenases to the greatest extent. The count of bacteria in the root zone of the tested plants, reduced under the influence of phenanthrene, could be the reason for the inhibition of the root growth. An opposite trend was recorded following the application of pyrene to the soil, which stimulated the count of microorganisms, while regardless of the plants being tested, the hydrocarbon inhibited the growth of their roots to the smallest extent. This could be related to both the progressive degradation of pyrene in the soil and the adaptation of plants to adverse conditions through an increase in the secretion of oxidoreductases released by the underground parts. Under the influence of polycyclic aromatic hydrocarbons, an increase in the microorganism population in the root zone of L. sativum, S. alba, and $S$. saccharatum could occur, which, in combination with extracellular enzymes, resulted in the stimulation of the root growth (Muratova et al. 2009). The bioavailability of phenanthrene to L. sativum was determined by Bogolte et al. (2007) who observed strong correlations between $\mathrm{PAH}$ accumulation in plants and extractability under mild conditions.

\section{Conclusions}

It was found that the tested PAHs increased the average colony counts of organotrophic soil bacteria; pyrene did so to the greatest extent (2.2-fold relative to non-contaminated soil), phenanthrene to the smallest extent (1.4-fold relative to noncontaminated soil). None of the PAHs changed the value of the bacterial colony development (CD) index, while anthracene and pyrene increased the value of the ecophysiological (EP) diversity indicator. PAHs lowered the activity of the tested enzymes. The activity of dehydrogenases was diversified to a greater extent by the type of hydrocarbon $(54.56 \%)$ rather than by the dose $(10.64 \%)$ thereof, while for the activity of urease, the situation was the opposite: greater extent by dose $(95.42 \%)$ than by type $(0.21 \%)$. Dehydrogenases are characterised by greater resistance to the action of PAHs than urease. Based on seed germination and root growth, it has shown that $S$. alba is best suited, being the most vulnerable plant, while $S$. saccharatum is the least suited. Subjecting a soil to strong pressure of PAHs leads to disturbances to the biological parameters of the soil, seed germination, and root growth L. sativum, S. saccharatum, and S. alba.

Open Access This article is distributed under the terms of the Creative Commons Attribution 4.0 International License (http:// creativecommons.org/licenses/by/4.0/), which permits unrestricted use, distribution, and reproduction in any medium, provided you give appropriate credit to the original author(s) and the source, provide a link to the Creative Commons license, and indicate if changes were made.

\section{References}

Alef K, Nannipieri P (1998) Methods in applied soil microbiology and biochemistry. Harcourt Brace \& Company, Publishers, London, pp 316-320

Amezcua-Allieri MA, Ávila-Chávez MA, Trejo A, Meléndez-Estrada J (2012) Removal of polycyclic aromatic hydrocarbons from soil: a comparison between bioremoval and supercritical fluids extraction. Chemosphere 86:985-993

Baran S, Bielińska JE, Oleszczuk P (2004) Enzymatic activity in an airfield soil polluted with polycyclic aromatic hydrocarbons. Geoderma 118:221-232

Bogolte BT, Ehlers GAC, Braun R, Loibner AP (2007) Estimation of PAH bioavailability to Lepidium sativum using sequential supercritical fluid extraction - a case study with industrial contaminated soils. Eur J Soil Biol 43:242-250

Bundy JG, Paton GI, Campbell CD (2004) Combined microbial community level and single species biosensor responses to monitor recovery of oil polluted soil. Soil Biol Biochem 36:1149-1159

Bunt YS, Rovira AD (1955) Microbiological studies of some subarctic soils. J Soil Sci 6:119-128

Carter MR (1993) Soil sampling and methods of analysis, Canadian society of soil science. Lewis Publishers, London

Das K, Mukherjee AK (2007) Crude petroleum-oil biodegradation efficiency of Bacillus subtilis and Pseudomonas aeruginosa strains isolated from a petroleum-oil contaminated soil from North-East India. Bioresour Technol 98(7):1339-1345

De Leij FAAM, Whipps JM, Lynch JM (1994) The use of colony development for the characterization of bacterial communities in soil and roots. Microb Ecol 27:81-97

Driscoll SBK, McArdle ME, Menzie AC, Reiss M, Steevens JA (2010) Framework for using dose as a metric to assess toxicity of fish to PAHs. Ecotoxicol Environ Saf 73:486-490

Hicks RJ, Stozky G, van Voris P (1990) Review and evaluation of the effects of xenobiotic chemicals on microorganisms in soil. Adv Appl Microbiol 35:195-253 
ISO 11261 (1995) Soil quality - Determination of total nitrogen Modified Kjeldahl method. TC 190/SC 3:4

Kanaly RA, Harayama S (2000) Biodegradation of high-molecularweight polycyclic aromatic hydrocarbons by bacteria. J Bacteriol 182:2059-2067

Klimkowicz-Pawlas A, Maliszewska-Kordybach B (2003) Effect of anthracene and pyrene on dehydrogenases activity in soils exposed and unexposed to PAHs. Water Air Soil Pollut 145(1-4):169-186

Kucharski J, Wyszkowska J (2000) Response of soil microorganisms and buckwheat plants to cytokinines. Rost Vyr 46(11):527-532

Li J, Liu GM, Yin LL, Xue JL, Qi H, Li YF (2013) Distribution characteristics of polycyclic aromatic hydrocarbons in sediments and biota from the Zha Long Wetland, China. Environ Monit Assess 185: 3163-3171

Lin C, Gan L, Chen ZL (2010) Biodegradation of naphthalene by strain Bacillus fusiformis (BFN). J Hazard Mater 182:771-777

Lipińska A, Kucharski J, Wyszkowska J (2013) Urease activity in soil contaminated with polycyclic aromatic hydrocarbons. Pol J Environ Stud 22(5):1393-1400

Lipińska A, Kucharski J, Wyszkowska J (2014a) The effect of polycyclic aromatic hydrocarbons on the structure of organotrophic bacteria and dehydrogenase activity in soil. Polycycl Aromat Compd 34(1):35-53

Lipińska A, Kucharski J, Wyszkowska J (2014b) Activity of arylsulphatase in soil contaminated with polycyclic aromatic hydrocarbons. Water Air Soil Pollut 225(9):2097

Maliszewska-Kordybach B, Smreczak B, Klimkowicz-Pawlas A (2013) The levels and composition of persistent organic pollutants in alluvial agriculture soils affected by flooding. Environ Monit Assess 185(12):9935-9948

Margesin R, Zimmerbauer A, Schinner F (2000) Monitoring of bioremediation by soil biological activities. Chemosphere 40:339-346

Meudec A, Poupart N, Dussauze J, Deslandes E (2007) Relationship between heavy fuel oil phytotoxicity and polycyclic aromatic hydrocarbon contamination in Salicornia fragilis. Sci Total Environ 381(1-3):146-156

Moscoso F, Teijiz I, Deive FJ, Sanromán MA (2012) Efficient PAHs biodegradation by a bacterial consortium at flask and bioreactor scale. Bioresour Technol 119:270-276

Muratova A, Golubev S, Wittenmayer L, Dmitrieva T, Bondarenkova A, Hirche F, Merbach W, Turkovskaya O (2009) Effect of the polycyclic aromatic hydrocarbon phenanthrene on Root exudation of Sorghum bicolor (L.) Moench. Environ Exp Bot 66:514-521

Nelson DW, Sommers LE (1996) Total carbon, organic carbon, and organic matter. In: Sparks DL (ed) Method of soil analysis: chemical methods. American Society of Agronomy, Madison, pp 1201-1229

Öhlinger R (1996) Dehydrogenase activity with the substrate TTC in: methods in soil biology. Schinner F, Öhlinger R, Kandeler E, Margesin R (eds), Springer Verlag Berlin Heidelberg: 241-243

Orwin KH, Wardle DA (2004) New indices for quantifying the resistance and resilience of soil biota to exogenus disturbances. Soil Biol Biochem 36:1907-1912

Park IS, Park JW (2011) Determination of a risk management primer at petroleum-contaminant sites: developing new human health risk assessment strategy. J Hazard Mater 2-3:1374-1380

Pedetta A, Pouyte K, Herrera Seitz MK, Babay PA, Espinosa M, Costagliola M, Studdert CA, Peressutti SR (2013) Phenanthrene degradation and strategies to improve its bioavailability to microorganisms isolated from brackish sediments. Int Biodeterior Biodegrad 84:161-167

Pelaez AI, Lores I, Sotre A, Mendez-Garcia C, Fernandez-Velarde C, Santos JA, Gallego JLR, Sanchez J (2013) Design and field-scale implementation of an "on site" bioremediation treatment in PAHpolluted soil. Environ Pollut 181:190-199
Sarathchandra SU, Burch G, Cox NR (1997) Growth patterns of bacterial communities in the rhizoplane and rhizosphere of white clover (Trifoliumrepens L.) and perennial ryegrass (Lolium Perenne L.) in long-term pasture. Appl Soil Ecol 6:293-299

Seo JS, Keum YS, Li QX (2009) Bacterial degradation of aromatic compounds. IJERPH 6:278-309

Shen G, Cao L, Lu Y, Hong J (2005a) Influence of phenanthrene on cadmium toxicity to soil enzymes and microbial growth (5 pp). Environ Sci Pollut Res 12(5):259-263

Shen G, Lu Y, Zhou Y, Hong J (2005b) Interaction of polycyclic aromatic hydrocarbons and heavy metals on soil enzyme. Chemosphere 61: $1175-1182$

Shen FT, Lin JL, Huang CC, Arun AB, Young LS, Young CC (2009) Molecular detection and phylogenetic analysis of the catechol 1,2dioxygenase gene from Gordonia spp. Syst Appl Microbiol 32:291300

Shen FT, Young LS, Hsien MF, Lin SY, Young CC (2010) Molecular detection and phylogenetic analysis of the alkane 1-monooxygenase gene from Gordonia spp. Syst Appl Microbiol 3:53-59

Smreczak B, Maliszewska-Kordybach B (2003) Seeds germination and root growth of selected plants in PAH contaminated soil. Fresenius Environ Bull 12:946-949

Statsoft Inc, Statistica (2010) (data analysis software system), version 9.1. www.statsoft.com

Toledo FL, Calvo C, Rodelas B, González-López J (2006) Selection and identification of bacteria isolated from waste crude oil with polycyclic aromatic hydrocarbons removal capacities. Syst Appl Microbiol 29:244-252

World Reference Base of Soil Resources (2014) A framework for international classification, correlation and communication. Word soils Resources Raport. 103, FAO, Rome

Wyszkowska J, Kucharski J (2000) Biochemical properties of soil contaminated by petrol. Pol J Environ Stud 9(6):479-485

Wyszkowska J, Kucharski J (2005) Correlation between the number of cultivable microorganisms and soil contamination with diesel oil. Pol J Environ Stud 14(3):347-356

Wyszkowska J, Kucharski M, Kucharski J (2006) Application of the activity of soil enzymes in the evaluation of soil contamination by diesel oil. Pol J Environ Stud 15(3):501-506

Wyszkowska J, Kucharski M, Kucharski J (2008) Role of actinomyces of the genus Streptomyces in alleviating the effects of soil contamination with diesel oil. Pol J Nat Sci 23(3):709-717

Wyszkowska J, Borowik A, Kucharski J, Baćmaga M, Tomkiel M, Boros-Lajszner E (2013) The effect of organic fertilizers on the biochemical properties of soil contaminated with zinc. Plant Soil Environ 59:500-504

Wyszkowski M, Ziółkowska A (2013) Content of polycyclic aromatic hydrocarbons in soils polluted with petrol and diesel oil after remediation with plants and various substances. Plant Soil Environ 59(7): 287-294

Xiao X, Chen H, Si CH, Wu L (2012) Influence of biosurfactantproducing strain Bacillus subtilis BS1 on the mycoremediation of soils contaminated with phenanthrene. Int Biodeterior Biodegrad 75:36-42

Yessicaa GP, Alejandroa A, Ronalda FC, Joséa AJ, Esperanzab MR, Martínez-Romero Esperanza Jesús Samuel CS, MaRemedios ML, Ormẽno-Orrillo E (2013) Tolerance, growth and degradation of phenanthrene and benzo[a] pyrene by Rhizobium tropici CIAT 899 in liquid culture medium. Appl Soil Ecol 63:105-111

Zafra G, Moreno-Montaño A, AbsalónÁ E, Cortés-Espinosa DV (2015) Degradation of polycyclic aromatic hydrocarbonsin soil by a tolerant strain of Trichoderma asperellum. Environ Sci Pollut Res 22(2): 1034-1042 